Thus our findings confirm that an elemental diet is an extremely useful method for inducing a remission in acute Crohn's disease, although it does not appear to protect against long-term relapse.

CO'M was the recipient of an Eton Fellowship. We are grateful to Miss P Hulme and her colleagues in the department of dietetics for their continued help in these studies.

Requests for reprints should be addressed to DrCO'Morain, Division of Clinical Sciences, Clinical Research Centre, Harrow, Middlesex HA1 3UJ.

\section{References}

1 Fischer JE, Foster GS, Abel RM, Abbott WM, Ryan JA. Hyperalimentation as primary therapy for inflammatory bowel disease. Am f Surg 1973;125:165-75.

2 Anderson DL, Boyce HW. Use of parenteral nutrition in treatment of advanced regional enteritis. Am $\mathcal{F}$ Dig Dis 1973;18:633-40.

3 Vogel CM, Corwin TR, Bane AE. Intravenous hyperalimentation in the treatment of inflammatory diseases of the bowel. Arch Surg 1974;180: 460-7.

${ }^{4}$ Reilly J, Ryan J, Strole W, Fischer J. Total parenteral nutrition and inflammatory bowel disease. Acta Chir Scand 1976;142, suppl 466:92-3.

${ }^{5}$ Stephens RV, Randall HT. Use of a concentrated balanced liquid elemental diet for nutritional management of catabolic states. Ann Surg 1969;170: 642-67.

6 Bury KD, Stephens RV, Randall HT. Use of a chemically defined, liquid elemental diet for nutritional management of fistulas of the alimentary tract. Am $\mathcal{F}$ Surg $1971 ; 121: 174-83$.

7 Voitk AJ, Echave V, Feller JH, Brown RA, Gurd FN. Experience with an elemental diet in the treatment of inflammatory bowel disease. Is this primary therapy? Arch Surg 1973;107:329-33.

8 Rochio MA, Cha CJM, Haas KF, Randall HT. Use of chemically defined diets in the management of patients with acute inflammatory bowel disease. Am $\cdot \mathcal{F}$ Surg $1974 ; 127: 469-75$.
9 Giorgini GL, Stephens RV, Thayer WR. The use of "medical by-pass" in the therapy of Crohn's disease: report of a case. Am F Dig Dis 1973; 18:153-7.

${ }^{10}$ Goode A, Hawkins ST, Feggetter JG, Johnston ID. Use of an elemental diet for long term nutritional support in Crohn's disease. Lancet 1976; i:122-4.

11 Segal AW, Levi AJ, Loewi G. Levamisole in the treatment of Crohn's disease. Lancet 1977 ;ii:382-4.

12 Tanner JM, Whitehouse RH, Marshall WA, Carter BS. Prediction of adult height from height, bone age, and occurrence of menarche, at ages 4 to 16 with allowance for midparent height. Arch Dis Child $1975 ; 50: 14-26$.

13 Wensenck F. Faecal flora of Crohn's patients. Serological differentiation between Crohn's disease and ulcerative colitis. In: Weterman IT, Pena AS, Booth CC, eds. The management of Crohn's disease. Amsterdam : Excerpta Medica, 1976.

14 Winitz MR, Adams DA, Seedman PN, Davis PN, Jayko LG, Hamilton JA. Studies in metabolic nutrition employing chemically defined diets. II. Effects on gut microflora populations. Am f Clin Nutr 1970;23: 546-59.

15 Attebery HR, Sutter VL, Finegold SM. Effect of a partially chemically defined diet on normal human fecal flora. Am $\mathcal{F}$ Clin Nutr $1972 ; 25$ : 1391-8.

16 Crowther JS, Drasar BS, Goddard P, Hill MJ, Johnson K. The effect of chemically defined diet on the faecal flora and faecal steroid concentrachemically defined diet on

17 Bounous G, Devroede GJ. Effects of an elemental diet on human faecal flora. Gastroenterology $1974 ; 66: 210-4$.

18 Denman AM. Nature and diagnosis of food allergy. Proc Nutr Soc 1979; 38:391-402.

19 Falchuk KR, Isselbacher KJ. Circulating antibody to bovine albumin in ulcerative colitis and Crohn's disease-characterisation of the antibody response. Gastroenterology 1976;70:5-8.

${ }^{20}$ Aufses AH, Kreel I. Ileostomy for granulomatous colitis. Ann Surg $1971 ; 173: 91-6$.

${ }^{21}$ McArdle AH, Brown RA, Echave V, Rivilis J, Thompson AG. Alterations in gastric and pancreatic secretion induced by the feeding of an elemental diet. Arch Fr Mal App Dig 1972;61:115C.

(Accepted 22 September 1980)

\title{
Pituitary responsiveness to gonadotrophin-releasing and thyrotrophin-releasing hormones in children receiving phenobarbitone
}

\author{
ANTONIO MASALA, TULLIO MELONI, SERGIO ALAGNA， PIER P ROVASIO, \\ GRAZIELLA MELE, VANNINA FRANCA
}

\section{Summary and conclusions}

The effect of long-term treatment with phenobarbitone on pituitary responsiveness to gonadotrophin-releasing hormone and thyrotrophin-releasing hormone was studied in 20 boys being treated with the drug to prevent febrile convulsions. Baseline concentrations of luteinising and follicle-stimulating hormones were reduced as well as the responses of these hormones to stimulation with gonadotrophin-releasing hormone. Baseline prolactin concentrations were raised in comparison with those in

Istituto di Patologia Speciale Medica, University of Sassari, Italy ANTONIO MASALA, MD, assistant SERGIO ALAGNA, MD, assistant PIER P ROVASIO, MD, assistant

Clinica Pediatrica, University of Sassari

TULLIO MELONI, MD, professor of paediatrics GRAZIELLA MELE, MD, assistant

VANNINA FRANCA, MD, assistant normal children. The response of prolactin to thyrotrophin-releasing hormone, however, was impaired only in the children who had been receiving the drug for a long time. Phenobarbitone had no effect on the secretion of growth hormone.

Further studies should be carried out to ascertain how long these effects on pituitary function last after phenobarbitone is withdrawn and whether this interference with pituitary function modifies the child's subsequent development.

\section{Introduction}

Long-term treatment with anticonvulsants such as phenytoin and phenobarbitone is useful in preventing febrile convulsions in children. It is generally accepted that to be effective treatment with phenobarbitone should be continued for several months at doses ranging from 3 to $5 \mathrm{mg} / \mathrm{kg}$ body weight daily, even in children who have had only one febrile seizure. ${ }^{12}$ Several centrally acting drugs interfere with the function of the 
hypothalamus-pituitary axis. We do not know, however, of any available data on the effects of long-term treatment with anticonvulsants on pituitary function. We studied the effects of long-term treatment with phenobarbitone on the pituitary responsiveness to combined administration of gonadotrophinreleasing hormone and thyrotrophin-releasing hormone in children who were receiving the drug to prevent febrile convulsions.

\section{Subjects and methods}

We studied 20 boys being treated with phenobarbitone and 10 normal boys of comparable age. Ages ranged from 15 to 24 months. Ten children had been receiving the drug (Luminalette, $5 \mathrm{mg} / \mathrm{kg}$ body weight daily at 2000) for three to nine months (group A), while 10 had been under treatment for 10 to 20 months (group B). The purpose, details, and possible risks of the study were explained in detail to the parents, who gave their consent. Studies started at 0800 , with the children fasting and recumbent. A 21-gauge scalp-vein needle was inserted in a cubital vein and patency achieved by a slow drip of physiological saline. After two baseline samples had been taken (at -15 and 0 minutes) all the subjects received an intravenous bolus of $25 \mu \mathrm{g}$ synthetic gonadotrophin-releasing hormone (Relisorm) plus $100 \mu \mathrm{g}$ synthetic thyrotrophin-releasing hormone(Relefact). Blood was collected 30,60, and 120 minutes thereafter. Blood samples for hormone analysis were promptly centrifuged and serum aliquots stored at $-20^{\circ} \mathrm{C}$ until required.

Serum concentrations of luteinising hormone were assayed by a specific double-antibody method ${ }^{3}$ sensitive to $0.5 \mathrm{IU} / 1$. Intra-assay and interassay variations were $2.5 \%$ and $11 \%$ respectively. Serum concentrations of follicle-stimulating hormone were assayed by a specific double-antibody method ${ }^{4}$ sensitive to $0.5 \mathrm{IU} / 1$. Concentrations of both these hormones are expressed as IU/1 of the second International Reference Preparation human menopausal gonadotrophin. Serum prolactin concentrations were measured by a double-antibody method $^{5}$ sensitive to $1 \mu \mathrm{g} / 1$. Intra-assay and interassay variations were $3.5 \%$ and $8.5 \%$ respectively. The results are expressed as $\mu \mathrm{g} / \mathrm{l}$. One microgram of the standard preparation used corresponds to $23 \mathrm{mU}$ of the WHO 71/222. All the reagents used in assays of luteinising hormone, follicle-stimulating hormone, and prolactin were obtained from Biodata, Milan, Italy. Serum growth hormone concentrations were assayed by a specific radioimmunoassay using reagents obtained as a commercial kit from Sorin, Saluggia, Italy. The method is sensitive to $0.1 \mu \mathrm{g} / \mathrm{l}$. Intra-assay variation was $5 \%$ and interassay variation $14 \%$. Two-tailed paired and unpaired Student's $t$ tests were used to analyse the data statistically. All the results are reported as means \pm SEM.

\section{Results}

The tables show the results in the three groups of children. Under control conditions the serum concentration of luteinising hormone in the normal children was $5 \cdot 1 \pm 1.04 \mathrm{IU} / 1$ (table I). This was significantly higher than the concentrations in groups $A$ and $B(2.25 \pm 0.52$ and $1.15 \pm 0.07 \mathrm{IU} / 1$ respectively; $p<0.01$ in both cases). The average concentration of follicle-stimulating hormone in the normal children was $4 \cdot 6 \pm 0.34 \mathrm{IU} / \mathrm{l}$. This was not significantly different from the concentration of $3.21 \pm 0.28 \mathrm{IU} / 1$ found in group $A(p>0.05)$ but was significantly higher than the $1.76 \pm 0.15 \mathrm{IU} / 1$ observed in group $B$ $(\mathbf{p}<0.01)$. Administration of gonadotrophin-releasing hormone induced a prompt, significant increase in concentrations of both luteinising hormone and follicle-stimulating hormone in the normal subjects. Peak concentrations of both hormones occurred 30 minutes after injection $(16 \cdot 16 \pm 2.96 \mathrm{IU} / 1$ and $12.66 \pm 2 \cdot 11 \mathrm{IU} / 1$ respectively; $\mathrm{p}<0.001$ ). In patients in group A gonadotrophin-releasing hormone induced a significant increase in concentrations of luteinising and follicle-stimulating hormones to peak values of $9.85 \pm 1.93$ and $7.66 \pm$ $1.98 \mathrm{IU} / 1$ respectively. The differences with respect to peak values observed in the normal subjects were significant $(p<0.01$ for luteinising hormone and $p<0.02$ for follicle-stimulating hormone) In patients in group $B$ the injection of gonadotrophin-releasing hormone induced only modest increments in concentrations of luteinising and follicle-stimulating hormones, which, though significant with respect to baseline values $(p<0.01)$, were significantly lower than those observed in the normal subjects $(p<0.01)$ and patients in group $A(p<0.01)$.
TABLE I-Serum concentrations of luteinising hormone and follicle-stimulating hormone $(I U \mid l)$ under control conditions and in response to administration of synthetic gonadotrophin-releasing hormone in normal children and children who had been receiving phenobarbitone for three to nine months (group $A$ ) and 10-20 months (group B)

\begin{tabular}{|c|c|c|c|c|c|c|}
\hline & & \multicolumn{5}{|c|}{ Minutes after injection } \\
\hline & & -15 & $\mathbf{0}$ & +30 & +60 & +120 \\
\hline \multicolumn{7}{|c|}{ Normal children $(n=10)$} \\
\hline $\begin{array}{l}\text { Luteinising } \\
\text { hormone } \\
\text { Follicle-stimulating } \\
\text { hormone }\end{array}$ & $\left\{\begin{array}{l}\text { Mean } \\
\text { SEM } \\
\text { Mean } \\
\text { SEM }\end{array}\right.$ & $\begin{array}{l}5 \cdot 18 \\
1 \cdot 98 \\
4 \cdot 83 \\
0 \cdot 26\end{array}$ & $\begin{array}{l}5 \cdot 10 \\
1 \cdot 94 \\
4 \cdot 16 \\
0 \cdot 34\end{array}$ & $\begin{array}{r}16 \cdot 16 \\
2 \cdot 96 \\
12 \cdot 66 \\
1 \cdot 23\end{array}$ & $\begin{array}{r}12 \cdot 83 \\
2.06 \\
9 \cdot 33 \\
0.65\end{array}$ & $\begin{array}{l}6 \cdot 30 \\
2 \cdot 80 \\
5 \cdot 20 \\
1 \cdot 03\end{array}$ \\
\hline \multicolumn{7}{|c|}{ Group $A(n=10)$} \\
\hline $\begin{array}{l}\text { Luteinising } \\
\text { hormone } \\
\text { Follicle-stimulating } \\
\text { hormone }\end{array}$ & $\left\{\begin{array}{l}\text { Mean } \\
\text { SEM } \\
\text { Mean } \\
\text { SEM }\end{array}\right.$ & $\begin{array}{l}2 \cdot 30 \\
0 \cdot 60 \\
3 \cdot 26 \\
0 \cdot 30\end{array}$ & $\begin{array}{l}2.25 \\
0.52 \\
3.21 \\
0.28\end{array}$ & $\begin{array}{l}9.85 \\
1.93 \\
7.86 \\
1.34\end{array}$ & $\begin{array}{l}8.00 \\
1 \cdot 28 \\
5 \cdot 25 \\
0.95\end{array}$ & $\begin{array}{l}3.36 \\
1.60 \\
3.60 \\
1.20\end{array}$ \\
\hline \multicolumn{7}{|c|}{ Group $B(n=10)$} \\
\hline $\begin{array}{l}\text { Luteinising } \\
\text { hormone } \\
\text { Follicle-stimulating } \\
\text { hormone }\end{array}$ & $\left\{\begin{array}{l}\text { Mean } \\
\text { SEM } \\
\text { Mean } \\
\text { SEM }\end{array}\right.$ & $\begin{array}{l}1 \cdot 14 \\
0 \cdot 08 \\
1 \cdot 78 \\
0 \cdot 18\end{array}$ & $\begin{array}{l}1.15 \\
0.07 \\
1.76 \\
0.15\end{array}$ & $\begin{array}{l}4 \cdot 36 \\
0 \cdot 28 \\
5 \cdot 60 \\
0 \cdot 20\end{array}$ & $\begin{array}{l}2 \cdot 70 \\
0 \cdot 39 \\
4 \cdot 30 \\
0 \cdot 18\end{array}$ & $\begin{array}{l}2.01 \\
0.80 \\
2 \cdot 16 \\
0.60\end{array}$ \\
\hline
\end{tabular}

Under control conditions the average baseline prolactin concentrations were $11.06 \pm 1.95,14.44 \pm 1.98$, and $22.0 \pm 2.39 \mu \mathrm{g} / 1$ in the normal subjects, patients in group $A$, and patients in group $B$ respectively (table II). Prolactin concentrations were higher in group B than the other groups $(p<0.01)$. Administration of $100 \mu g$ synthetic thyrotrophin-releasing hormone increased prolactin concentrations in all the subjects studied. Peak concentrations were $42.0 \pm 4.50 \mu \mathrm{g} / 1$ in the normal children, $40.08 \pm 5.93 \mu \mathrm{g} / 1$ in the children in group $A$, and $29.67 \pm 1.26 \mu \mathrm{g} / \mathrm{l}$ in the children in group $B$.

TABLE II-Serum prolactin concentrations $(\mu g / l)$ under control conditions and in response to administration of synthetic thyrotrophin-releasing hormone in normal children and patients who had been receiving phenobarbitone for three to nine months (group $A$ ) and 10-20 months (group B)

\begin{tabular}{lrcccr}
\hline \multicolumn{6}{c}{ Minutes after injection } \\
\cline { 2 - 6 } & -15 & 0 & +30 & +60 & +120 \\
\hline \multicolumn{7}{c}{ Normal children $(n=10)$} \\
Mean & 12.81 & 11.63 & 42.00 & 30.33 & 16.15 \\
SEM & 2.05 & 1.95 & 4.50 & 3.77 & 3.55 \\
Mean & 15.25 & 14.44 & 40.00 & 28.02 & 18.04 \\
SEM & 2.21 & 1.96 & 5.35 & 3.23 & 2.13 \\
& \multicolumn{7}{c}{ Group $A(n=10)$} \\
Mean & 23.25 & 22.00 & 29.67 & 24.60 & 23.00 \\
SEM & 2.50 & 2.39 & 1.26 & 2.09 & 1.37 \\
\hline
\end{tabular}

All these values were significantly higher than the baseline concentrations $(p<0.01)$. Whereas no difference was found between the peak values observed in the normal children and those in group $A$, the difference between the peak concentrations in the normal children and the children in group B was highly significant $(p<0.001)$.

Gonadotrophin-releasing hormone plus thyrotrophin-releasing hormone had no effect on serum concentrations of growth hormone. The average baseline concentrations of growth hormone were $1.34 \pm$ $1.25,1.83 \pm 1 \cdot 18$, and $1.66 \pm 1.08 \mu \mathrm{g} / 1$ in the normal children and those in groups A and B respectively. No significant modifications were recorded throughout the observation period $(p>0.05)$, nor were any side effects observed.

\section{Discussion}

The results of this study indicate that long-term treatment with phenobarbitone in children with febrile convulsions may modify basal as well as stimulated secretion of gonadotrophin and prolactin. Experimental data have shown that barbiturates may interfere with the release of gonadotrophins, presumably by acting on the central nervous system by inhibiting secretion of gonadotrophin-releasing hormone. ${ }^{7}$ In particular, pheno- 
barbitone may block spontaneous and gonadotrophin-stimulated ovulation in the rat, an effect that may be reversed by progesterone. $^{8} 9$ Our results show that pituitary responsiveness to gonadotrophin-releasing hormone is impaired during longterm treatment with phenobarbitone. This may be due to an effect on central nervous system sites, although direct action at the pituitary cannot be excluded. In contrast with previously reported experimental data, secretions of both luteinising hormone and follicle-stimulating hormone seem to be impaired. ${ }^{\circ}$ Baseline prolactin concentrations were higher in the children treated with the drug than in the control subjects, the highest concentrations being observed in those treated the longest. While enhancing basal prolactin secretion, however, phenobarbitone reduced the release of prolactin induced by thyrotrophin-releasing hormone. Chronically raised prolactin concentrations may interfere with the pituitary-gonadal axis in man, ${ }^{10}$ though this requires further elucidation. The raised prolactin concentrations observed in the children treated the longest might have contributed to the impaired pituitary gonadotrophin secretion. Long-term treatment with phenobarbitone has no effect on basal secretion of growth hormone. Moreover, no abnormal release of growth hormone was observed in response to gonadotrophin-releasing and thyrotrophin-releasing hormones. Although specific tests on secretion of growth hormone were not performed, this may indicate that the drug does not interfere with the neural and aminergic mechanisms controlling release of growth hormone in man.

If the results of the present study are confirmed on a larger number of patients, children treated with phenobarbitone should be studied to ascertain how long those effects on pituitary function last after withdrawal of the drug. Moreover, longitudinal studies may help to ascertain whether this interference with pituitary function leads to modifications in the child's development.

The skilled help of Mrs Jennifer Martin is gratefully acknowledged.

\section{References}

1 Wolf SM. The effectiveness of phenobarbital in the prevention of recurrent febrile convulsions in children with and without a history of pre-, periand postnatal abnormalities. Acta Paediatr Scand 1977;66:585-7.

2 Wolf SM, Carr A, Davis DC, et al. The value of phenobarbital in the child who has had a single febrile seizure : a controlled prospective study. Pediatrics 1977;59:378-84.

${ }^{3}$ Midgley AR. Radioimmunoassay: a method for human chorionic gonadotropin and human luteinizing hormone. Endocrinology 1966;79:10-8.

4 Midgley AR. Radioimmunoassay for human follicle-stimulating hormone. f Clin Endocrinol Metab 1967;27:295-9.

5 McNeily AS. Radioimmunoassay for human prolactin. Proc $R$ Soc Med $1973 ; 66: 683-4$

${ }^{6}$ Borrel J, Piva F, Martini L. Effect of pentobarbital on serum levels of LH, FSH and prolactin in long-term ovariectomized rats. Neuroendocrinology $1978 ; 27: 239-46$

7 Wuttke W, Meites J. Effect of ether and phenobarbital on serum prolactin and LH levels in proestrus rats. Proc Soc Exp Biol Med 1970;135:648-52.

${ }^{8}$ Markó M, Flückiger E. Inhibition of spontaneous and induced ovulation in rats by non-steroidal agents. Experientia 1974 ;30:1174-6.

${ }^{9} \mathrm{McC}$ Cormack CE, Strauss WF. Reversal by progesterone of phenobarbitalblockade of the ovulation in the prepubertal rat primed with pregnan mare serum gonadotrophin. F Endocrinol 1975;65:177-82.

10 Thorner MO, Besser GM. Hyperprolactinaemia and gonadal function results of bromocriptine treatment. In: Crosignani PG, Robyn C, eds. Prolactin and human reproduction. London and New York: Academic Press, 1977:285-301.

(Accepted 24 fuly 1980)
ONE HUNDRED YEARS AGO We are happily absolved, by the absorption of our space with the proceedings of the annual meeting of the Association at Cambridge, from devoting much space to the unhappy proceedings in connection with the trial of the nurse Ingle for manslaughter of a patient at Guy's Hospital, in the wards of Dr Pavy, by the prolonged administration of a "punishment-bath," which produced an immediately injurious effect upon the patient, and accelerated her death. A few observations must, however, be made upon the facts before the public. In the first place, it is inconceivable in these days that there should have existed in the mind of any hospital nurse the theory that, under any circumstances whatever, she could be authorised to administer what is, to our amazement, spoken of calmly, and as a matter of justificatory description, as a punishment-bath. There are bad old traditions of the administration of torture of this kind in the bad old days of lunatic asylums, and in prisons; but they lingered in the recollection only as extinct abuses, classed with the gone-by horrors of the cruel jailer and the harsh keeper of an age which has passed away. A punishment-bath has long been recognised as a means not less dangerous than cruel, even when administered to strong and healthy persons. If we had heard of a punishment-bath ten years ago in a workhouse infirmary of the extinct class, as they existed before Dr Anstie and Mr Ernest Hart let in the light of day upon them, and swept away the abuses which still lingered in them as the worst and most corrupt existing refuge for the sick, we should have pointed to such an abomination as of itself enough to condemn the administration and its officers. To hear of the secret administration of torture or "punishment" by the bath by a nurse in one of our great public hospitals, the pride and glory of the metropolis, one of the chief seats of medical education, and where some of the greatest living medical men preside-or, as it now seems, are supposed to presideover the wards, is not less surprising than it is shocking. We have said nothing on this subject while the trial was pending, lest it might seem to in some way prejudge the facts and prejudice the case of the prisoner; but, now that the case is over, we must say that the proof that such an act as the administration of a "punishment-bath," whether of an hour or an hour and a half, or indeed of ten minutes, could be possible in a metropolitan hospital, is a revelation. It is a revelation of the most grievous and startling kind, that the "ladysuperintendent" of any hospital should so arrange the system of nursing, or should permit the existence of such a theory or spirit of nursing, as to make it possible that any nurse should think herself entitled to inflict physical punishment on sick people. That a nurse should drag an unwilling patient to a bath, is in itself an assault of an aggravated kind. That she should, as an act of punishment, immerse her in water for a prolonged period, is an assault of a peculiarly dangerous kind; and, whatever had been the issue, whether fatal or not, it cannot be said that a short term of imprisonment is too severe a punishment for so gross an offence. It reflects most severely upon the whole spirit existing in the nursing establishment of Guy's, that such an act should be possible. Even in prisons, when physical punishments are inflicted, the medical officer is informed beforehand, and his authority is recognised. But, happily, hospitals are not prisons or houses of correction; and it certainly is not the intention either of the public or of the medical profession that they should be converted into places of punishment for the sick. The theory that the nurse is to be told whether, in the opinion of the doctors, there exists in each patient a substratum of hysteria or the seeds of brain-disease, in order that she may of her own wisdom and mercy adjust the severity of the punishment which she may think it well to inflict to the capacity of endurance of the patient's diseased constitution, is altogether a new one. As the ingenious defence of an advocate, driven to invent a theory for the escape of the prisoner whom he is shielding, it is not devoid of striking originality and audacious effect. As a working guide for hospital management, it was reserved for the present lay administrators of Guy's Hospital to see such a state of things brought to light as to make it necessary for an able advocate to manufacture this theory on the floor of a criminal court, to mitigate the punishment awaiting the acts which have been proved to have occurred. We may well hope that such a state of things will soon cease. The sacrifice of principles to persons has surely been carried far enough; and this last ineffable disgrace to one of the greatest and most noble of our hospitals, whose history has been bound with traditions so very different, must surely point to the necessity of reversing a policy which has recently been one of personal bravado of the counsels and wishes of the medical officers, whose opinions and wishes ought certainly to be supreme in all that relates to the nursing of the patients, for whose well-doing they are mainly responsible. Two resignations would restore peace and efficiency; when will they be tendered? (British Medical fournal, 1880.) 